\title{
Графский титул \\ в контексте Петровской карнавальной культуры
}

\author{
Борис Андреевич Успенский \\ Национальный исследовательский университет «Высшая школа \\ экономики» \\ borisusp@gmail.com
}

\begin{abstract}
:
The Title of Count in the Context of Petrine Carnival Culture

The europeanization of Russia under Peter I had a conspicuously carnival form. Characteristically, the reforms of Peter I, which were intended to turn Russia into a European country, in many cases began with carnival sport. Carnavalization, re-naming-all this manifested a general cultural program, which reveals the artificial character of the modernization of Russia. Russian official life turned out to be extremely carnivalesque. Carnival became an element of Russian court life; participation in carnivals was obligatory. Together with new clothing, new language and new habits, new aristoricratic titles were adopted, such as count or baron. In the context of carnival ceremonies such titles had an ambiguous character. The author attempts to demonstrate that the title of count could be understood as buffonesque in the Petrine epoch.
\end{abstract}

Keywords:

Peter I; titles of honor and nobility; court jesters; N. M. Zotov; Lacosta; carnival

“... лежу себе как этакой граф Бутылкин” Достоевский, Записки из Мертвого дома

1. Европеизация России при Петре I имела откровенно карнавальный характер. ${ }^{1}$ Действительно, реформы Петра I, призванные преобразовать Россию, начинались обычно именно с карнавальной игры. Так “потешные" войска, созданные в начале 1680-х гг. для “военных потех" царевича Петра, положили начало образованию регулярной армии. Точно так же церковной реформе Петра, в результате которой отношения церкви и государства были ориентированы на европейскую модель, принятую в протестантских странах, - предшествовали шутовские церемонии Всепьянейшего собора: церковная реформа начинается с непристойной и кощунственной пародии на церковь. Равным образом пародирование традиционного облика русского царя на шутовских свадьбах предвосхищало принятие Петром императорского титула, когда Петр провозглашает себя “императором" и “отцом отечества” (pater patriae) - так, как назывались римские императоры. Одновременно Петр называет себя "Великим": он именует себя "Великим" и "Первым" потому, что в истории под такими именами фигурируют западные монархи.

Переодевание, переименование - все это было проявлением общей культурной политики, свидетельствующей об искусственном характере европеизации России. Появляются новые имена городов, составленные из

\footnotetext{
${ }^{1}$ См. подробнее: Б.А. Успенский, “Европа как метафора и как метонимия (применительно к истории России).” В изд.: Б.А. Успенский, Историко-филологические очерки (М., 2004), 9-26, здесь 18-26.
} 
иностранных слов, — такие, как Санкт-Петербург, Шлиссельбург и другие. Ранее подобные названия воспринимались как “потешные,” игровые (ср. “потешный городок” Пресбург, который строит молодой Петр в Преображенском); теперь же так называется новая столица Российского государства.

Наконец, кардинальным образом меняется официальный язык: он пестрит заимствованиями. Это относится, в частности, и к новым титулам и званиям, появляющимся в петровской России: они вписываются в общий процесс карнавализации.

2. В допетровской России существовал лишь княжеский титул: он обозначал принадлежность к роду, у истоков которого стоял независимый правитель какой-то территории, вошедшей затем в Московское царство; соответственно, князья могли иметь варяжское (Рюриковичи), литовское (Гедиминовичи), татарское или мордовское происхождение. Княжеский титул был потомственным и не мог жаловаться царем: князем в принципе невозможно было стать, им надо было родиться. Петр впервые нарушает эту традицию, сделав в 1707 г. А. Д. Меншикова российским князем, т. е. пожаловав ему княжеское достоинство Российского царства; перед этим в 1705 г. Меншиков стал князем Священной Римской империи. Это был единственный и беспрецедентный случай такого рода - единственный не только в царствование Петра, но и в последующие царствования, вплоть до последних лет XVIII в. Лишь при Павле - через девяносто лет возобновляются пожалования в князья, ${ }^{2}$ после чего такого рода практика становится нередким явлением. Соответственно, с начала XVIII в. оказывается возможным лишение княжеского титула по Высочайшему указу (подобно тому, как можно было лишить титула графа или барона); ${ }^{3}$ ранее же этот титул был неотъемлемой (неотчуждаемой)

2 В 1797 г. княжеский титул Российской империи получает А. А. Безбородко (с наименованием “светлости”), в 1799 г. - П. В. Лопухин (с наименованием “светлости”) и А. В. Суворов (без наименования “светлости”), в 1800 г. - армянский католикос Иосиф Аргутинский-Долгорукий с братьями и племянниками (без наименования “светлости”).

При Екатерине II княжеский титул (с наименованием “светлости”) носили три ее фаворита - Г. Г. Орлов (1772 г.), Г. А. Потемкин (1776 г.) и П. А. Зубов (1796 г.), 一 но всякий раз это был титул Священной Римской, а не Российской империи. Перед получением княжеского титула каждый из них получил титул графский (Г. Г. Орлов в 1762 г., Г. А. Потемкин в 1775 г. стали графами Российской империи, П. А. Зубов в 1793 г. - графом Священной Римской империи).

3 Так, в 1727 г. был лишен этого титула А. Д. Меншиков (княжеское достоинство было возвращено его сыну А. А. Меншикову в 1731 г.), в 1730 г. - князья А. Г. и И. А. Долгоруковы, в 1826 г. - восемь князей-декабристов: А. П. Барятинский, С. Г. Волконский, В. М. Голицын, Е. П. Оболенский, А. И. Одоевский, С. П. Трубецкой, Ф. П. Шаховской, Д. А. Щепин-Ростовский, в 1861 г. - князь В. П. Долгоруков.

Графского титула был лишен в 1727 г. П. А. Толстой, произведенный в графы 8 мая 1724 г. (по случаю коронации Екатерины I); графское достоинство было возвращено его внукам в 176о г. Баронского титула лишился в 1723 г. П. П. Шафиров, ставший российским бароном 30 мая 1710 г. (в день рождения царя; до этого, в 1709 г., Шафиров стал бароном Священной Римской империи); баронское достоинство было возвращено ему в 1726 г. 
принадлежностью человека. Лишение княжеского титула было столь же беспрецедентным, как и его пожалование. То и другое прямо связано: княжеского титула можно лишить именно потому, что он может быть пожалован. Так княжеский титул приобретает черты придворного титула.

Вскоре после того, как Меншиков был произведен в князья, Петр начинает жаловать в графы и в бароны. Мысль об этом возникает у него много раньше 4 - примерно тогда же, по-видимому, когда Петр стал именовать себя (неформально) “императором." Совершенно очевидно, что Петр ориентируется при этом на императора Священной Римской империи: он усваивает прерогативы западного монарха, т.е. имеет место имитация западноевропейского государства. Так же, как и в случае Меншикова, пожалованию в российские графы и бароны первоначально предшествовало получение соответствующего титула Священной Римской империи. Так, А. Д. Меншиков сначала становится князем Священной Римской империи (1705 г.), а потом - князем российским (1707 г.). Г. И. Головкин сначала становится графом Священной Римской империи (1707 г.), а потом - графом российским (1710 г.). П. П. Шафиров становится бароном Священной Римской империи (1709 г.) и затем российским бароном (1710 г.). Вместе с тем, в 1710 г. в графское достоинство возводятся и те, кто никогда не был графом Священной Римской империи (Ф. М. Апраксин, И. А. Мусин-Пушкин, Н. М. Зотов, Б. П. Шереметев): они становятся российскими графами непосредственно, минуя соответствующий титул Священной Римской империи.

3. Итак, с 1710 г. на Руси появляются первые российские графы и бароны. Отметим, что пожалование в князья Меншикова в 1707 г. было связано с усвоением ему определенной территории, название которой входило в его титул: Меншиков был пожалован не просто в князья, но “в князи Ижерския земли” " и, соответственно именовался “князем Ижорским” - с титулом “светлости” (последний призван был напоминать о принадлежавшем ему титуле князя Священной Римской империи). ${ }^{7}$

\footnotetext{
${ }^{4}$ Уже ок. 1700 г. появляется формулярный документ “Проект диплома, графам даваемого” (Российский государственный архив древних актов [далее РГАДА], ф. 154, оп. 2, д. 15), ср. затем "Проект, каким образом пишутся дипломы на достоинство российского графа" (там же, ф. 154, оп. 2, д. 392).

${ }^{5}$ Хотя формально Петр стал императором в 1721 г., фактически он назывался таким образом и раньше, по крайней мере за четверть века до официального принятия императорского титула - впервые, кажется, после Азовской победы 1696 г. и затем особенно часто после Полтавской победы 1709 г. См.: Б.А. Успенский, "Царь и самозванец: самозванчество в России как культурно-исторический феномен." В изд.: Б.А. Успенский, Избранные труды, т. І: Семиотика истории; семиотика культуры. Изд. 2-е, испр. и переработ. (М., 1996), 142-183, здесь 176-177, примеч. 36.

${ }^{6}$ В дипломе (жалованной грамоте) на княжеское достоинство говорилось о том, что Меншиков становится "Всероссийского нашего царствия князем Ижерския земли"; при этом Меншикову и его потомкам отдавались в вечное владение "во оном княжестве лежащия грады Ямбурк и Копорье с принадлежащими к ним уезды и землями.” Письма и бумаги императора Петра Великого (т. I-XIII. СПб./М., 1887-2003 [далее ПиБ]), V, 284$290\left(\mathrm{~N}^{\circ} 1779\right)$.

${ }^{7}$ Одновременно он называл себя и “герцогом Ижорским,” вписываясь таким образом в
} 
Ижорская земля была незадолго перед тем отвоевана у шведов (в 1703 г.), т.е. это была только что присоединенная территория (правда, ранее входившая в состав Русского царства). Вместе с тем, в том же 1707 г., когда был пожалован в князья Меншиков, Петр хотел привлечь Джона Черчилла, герцога Мальборо, который желал получить в России княжество. За посредничество в примирении со шведами, Петр обещал ему Киевское, Владимирское или Сибирское княжество, какое тот захочет (дело не состоялось). ${ }^{8}$ Замечательно, что на этот раз Петр готов был отдать Черчиллу не новоприобретенную территорию (какой была Ижорская земля), но исконные русские земли, которые входили в царский титул. ${ }^{9}$ Вероятно, наименование такого рода было бы чисто номинальным: существенно во всяком случае, что пожалование в князья при Петре связывалось с определенной территорией и предполагало наименование по этой территории.

Так обстояло дело с княжеским титулом. Между тем графы и бароны, произведенные в России, никак не были связаны (пусть даже и номинально) с заранее известной территорией (за одним исключением, о котором будет сказано ниже); титул их сам по себе не предполагал такого рода ассоциаций. Это превращало их титул в чисто условное звание, лишая его какой бы то ни было исторической или административной мотивации. Поэтому с самого начала этот титул мог, видимо, восприниматься как потешный, шутовской: наряду с графамивельможами, в России изначально были графы-шуты, и различить их не

западноевропейский культурный контекст, - термины “князь” и “герцог” при этом выступают как равноправные. Характерно в этом смысле, что дети Меншикова именовались “принцами.” Е.П. Карнович, Родовые прозвания и титулы в России (СПб, , 1886). Репринт: (М., 1991), 185. Впрочем, так могли называть и самого Меншикова; см., например, в письме Д. Г. Ржевской к царю от 2 октября 1708 г. - М. И. Семевский, Слово и дело! 1700-1725 (СПб., 1885), 333.

${ }^{8}$ Ср. набросок ответа для письма к Гюйссену (январь-февраль 1707 г.): “На ево [барона Генриха фон Гюйссена] вопрошение, что дук Малбурк желает княжества из Руских, на то отписать к Геезену, естли то так и вышереченной дук к тому склонен, то обещать ему из трех которое похочет: Киефъское, Владимирское или Сибирское, и при том склонить ево, чтоб оной вспомог у королевы о добром миру с Шведом, обещая ему, ежели он то учинит, то со онова княжества по въся годы жизни ево непъременно дать будем по 50000 ефимков битых, також камень рубиин [sic!] (которово прислана будет медаль), какова или нет или зело мало такого величества в Еуропе, такоже и орден светаго Андрея прислан будет.” ПиБ, V, 6о ( $\left.\mathrm{N}^{\circ} 1551\right)$; О.И. Хоруженко, Дворянские дипломы ХVIII века в России (М., 1999), 24.

9 Ср. царский титул Петра: “Божиею милостию, Мы, пресветлейший и державнейший Великий Государь Царь и Великий Князь Петр Алексеевич, всея Великия и Малыя и Белыя России Самодержец Московский, Киевский, Владимирский, Новгородский, Царь Казанский, Царь Астраханский, Царь Сибирский, Государь Псковский и Великий Князь Смоленский, Тверский, Югорский, Пермский, Вятский, Болгарский и иных Государь и Великий Князь Новагорода Низовския земли, Черниговский, Рязанский, Ростовский, Ярославский, Белоозерский, Удорский, Обдорский, Кондийский, и всея Северныя страны Повелитель и Государь Иверския земли, Карталинских и Грузинских Царей, и Кабардинские земли, Черкасских и Горских Князей и иных многих государств и земель, восточных и западных и северных, отчич и дедич, и наследник, и Государь, и Обладатель." 
всегда просто. Не исключено, что первоначально между ними и не было сколько-нибудь очевидного различия.

4. Так, в 1710 г. графский титул получил всешутейший патриарх Никита Моисеевич Зотов. Этот титул был пожалован ему “при получении ведомости о взятии города Риги." ${ }^{\prime \prime}$ Хотя в дипломе (жалованной грамоте), выданном ему в 1713 г., значилось, что графское достоинство переходит к его потомкам обоего пола, ${ }^{11}$ после смерти Н. М. Зотова в 1717 г. его сыновьям и внукам запрещено было называться графами. ${ }^{12}$ Приходится объяснять это тем, что это был шутовской, потешный граф: в качестве шутовского титул графа не переходил по наследству. Вместе с тем, при жизни Зотова никто, как будто, не рассматривал Зотова как потешного графа. Скорее всего графский титул был признан шутовским задним числом, post factum.

Сходным образом в 1718 г. в графы был произведен шут Лакоста
(д'Акоста). ${ }^{13}$ И в этом случае графский титул не перешел к его

10 ПиБ, Х, с. 221 ( ${ }^{\circ}$ 3855); Древняя российская вивлиофика ... изданная Николаем Новиковым. Изд. 2-е, вновь испр. ... (ч. І-XX. М., 1788-1791 [далее Древняя российская вивлиофика]), IX, 476 ( $\left.\mathrm{N}^{\circ} \mathrm{XI}\right)$.

${ }^{1 "}$ Древняя российская вивлиофика, IX, 477-484 (N XII), ср. особенно 481 и 483. См. также: Хоруженко, Дворянские дипломы, 28 и 177 ( $\left.{ }^{\circ} 6\right)$.

${ }^{12}$ Впоследствии Высочайшими указами от 21 июня 1802 г. и 12 июля 1804 г. правнукам Никиты Моисеевича Зотова - прапорщику Николаю и коллежскому асессору Александру Ивановичам Зотовым - разрешено называться графами. В.А. Корсакова, “Зотов Никита Моисеевич," Русский биографический словарь, т. "Жабокритский Зяловский" (Пг., 1916), 476-481. Не именуясь графами, дети Зотова пользовались в печатях графским гербом, описанным в дипломе на графство, выданном его отцу. Хоруженко, Дворянские дипломы, 28.

${ }^{13}$ Cм.: [F. W. von Bergholz], Дневник камер-юнкера Ф. В. Берхгольца (1721-1725) (ч. I-IV. Перев. с нем. И. Ф. Аммона. Новое [3-е] изд. с доп. и примеч. М., 1902-1903), III, 121; [Fr. Chr. Weber], Das veränderte Rußland [...]. Neu-Verbesserte Auflage (Theil I-III. Franckfurth und Leipzig, 1738-1740), I, 339 (§ 432); [Jean Rousset de Missy], Memorie del Regno di Pietro il Grande, imperadore di Russia, padre della patria, ec. ec. ec. del B. Iwan Nestesusuranoi, divise in quatro tomi, nuovemente tradotte dal francese nel volgare italiano (t. I-IV. Venezia, 1736), IV, 213; [A. Catiforo], Житие Петра Великаго императора и самодержца всероссийскаго, отца отечества, собранное из разных книг, во Франции и Голландии изданных, и напечатанное в Венеции, Медиолане и Неаполе на диалекте италианском, а потом и на греческом, с коего на российской язык перевел [в 1743 г. по повелению императрицы Елизаветы Петровны-Б.У.] статский советник Стефан Писарев. СПб., 1772), 408-409; И.И. Голиков, Деяния Петра Великаго, мудраго преобразителя России, собранныя из достоверных источников и расположенныя по годам (ч. I-XII. M., 1788-1789), VII, 37; ср. также: В. Фурсенко, “Лесток," Русский биографический словарь, т. "Лабзина - Лашенко" (Пг., 1914), 323-346, здесь 325; Хоруженко, Дворянские дипломы, 48-51. И. И. Голиков упоминает об этом под 1719 г. (со ссылкой на сообщение П. Н. Крекшина), но речь идет о событиях, предшествующих этому времени. Ж. Руссе де Мисси и А. Катифор ничего не говорят о том, когда Лакоста стал именоваться графом. Вебер именует его “Titular-Graf.”

По сообщению Голикова, Лакосту привез в Россию русский резидент в Гамбурге; в России “помянутого Дакосту монарх сделал главным над шутами и называл его Графом"; резидентура в Гамбурге была с 1709 по 1713 г., резидентом был Иоганн Фридрих Бёттингер (1659-1739). Ср. сходные сведения в письме Лави (de la Vie), французского посланника в Петербурге, кардиналу Гийому Дюбуа (Guillaume Dubois) от 29 октября 1717 г. См. Сборник Русского исторического общества (т. I-CXLVIII. СПб., 1867-1916), XXXIV 
наследникам. В данном случае производство Лакосты в графы сопровождалось пожалованием владения, но само пожалование это имело откровенно условный, карнавальный характер, что, очевидно, отвечало карнавальному характеру самого титула. О. И. Хоруженко удалось обнаружить отпуст (черновой вариант) жалованной грамоты Петра I от 3 августа 1718 г., где “бл[а]гошляхетной Господинъ Кортизесъ Дакоста Церемоніи Мейстеръ Генеральнои"14 возводится в графы и становится владетелем острова Сомерс близ Ревеля (он именуется теперь “граөство Сомерсъ”) “со всеми шбретающимися Замками, Дистриктами и поселениями въ въчное владъние,” с правом “всъ доходы, какого ьвания оныя ни были собирать i употреблять по своему самовластному расположению. И никакія подати и контрибуціи с того Граөства Сомерсъ в нашу Казну збираны да не будутъ і всъмъ н[а]шимъ върнымъ подданнымъ всем[и]л[о]стивъйше повельваемъ, дабы по силь сего нашего соизволенія в вышеозначенное Граөство Сомерсъ ни под какимъ предлогом не интересовалис[ь] і со шбывателеи Фнаго денежных и протчихъ поборовъ Фтнюдь не вымогали... И то Граөство Сомерсъ кромъ его господина Церемоніи Мейстера Генералного гако суврена никому подчинено быть не имъетъ." 15 Остров этот, небольшой по размеру, состоял из камня и песку, и на нем никто не жил. Ср. дневниковую запись $\Phi$. Берхгольца под 1 августа 1723 г.: “стали опять на якоре в нескольких милях от острова Гохланда, против песчаного острова Сомерӧе... Сомерӧе есть то самое графство, которое Ла-Коста получил в подарок от императора. Оно состоит все из камня и песку и не имеет вовсе жителей."16

Таким образом, формально Лакоста стал владетельным графом, но владения его имели номинальный характер.

Позднее (29 августа 1740 г.), в царствование Анны Иоанновны, выходит именной указ “о приписке к публичным деревням и об отдаче в арендное содержание пожертованных бывшему церемониймейстеру Иоганну Дакосту островов Гохланда, Зеицкар, Лавек-ари и Титер-сарии."17

(1884), 259; Хоруженко, Дворянские дипломы, 48-49.

${ }^{14}$ Первоначально было указано его происхождение: “Из ... Гишпанской и Евреискои Өамиліи урожденнои”; слова эти были затем зачеркнуты.

${ }^{15}$ РГАДА, ф. 154, оп. 2, д. 146, л. 1-3 об. Ср.: Хоруженко, Дворянские дипломы, 50 и 179 (№ 12). Хоруженко говорит, что Лакосте пожалованы были в вечное владение два острова: Сомерс и Зецкер, однако в жалованной грамоте последовательно упоминается лишь “графство Сомерс." Название Зецкер приписано на полях л. 1 об., но непонятно, к чему оно относится. Остров Зецкер также был необитаем. Позднее он числится среди других островов, подаренных Петром Лакосте.

“Жалованная грамота церемонимейстеру Кортизесу Дакоста на остро[в] близъ Ревеля Сомерсъ и на графское достоинство" дана была на корабле "Ингерманландъ" (“Ингерманландия”), когда у царя пировали адмирал и все офицеры. См.: Походный журнал 1718 года (СПб., 1855), 36.

${ }_{16}^{16}$ Дневник камер-юнкера Ф. В. Берхгольца, III: 121.

${ }^{17}$ П. Баранов (сост.), Опись высочайшим указам и повелениям, хранящимся в С.Петербургском сенатском архиве за XVIII век (т. I-III. СПб., 1872-1878), II, 693 (№ 7860).

Известно, что Лакоста был шутом при дворе Анны Иоанновны. См.: [Cristof Hermann Manstein], Memoires historiques, politiques et militaires sur la Russie, contenant les 
Остров Гохланд или Гогълант (Hogland) был подарен Петром I Лакосте в 1721 г., вероятно, еще до заключения Ништадского мира; ${ }^{18}$ по- видимому, и это был чисто условный подарок, поскольку остров был занят шведами. Как бы то ни было, в 1723 г. Лакоста послал “сына своего, чтобы он вышепомянутый остров [Гохланд] принял," ${ }^{19}$ однако тот встретил противодействие со стороны шведского морского офицера, представлявшего там, по-видимому, шведскую администрацию; в 1724 г. Лакоста покупает этот остров, присоединяя его к своим владениям; в том же году Лакоста добивался права на беспошлинную торговлю рыбой в Ревельском дистрикте. ${ }^{20}$

В 1741 г. в Сенате слушалось дело по иску дочерей “бывшего церемонийместера Ивана Кортазена Дакоста,” Сарры и Екатерины, “о пожаловании им, для владения, на остров Самерс, лежащий близь Ревеля (который, по именному указу блаж[енной] и вечно дост[ойной] пам[яти] е[го] и[мператорского] в[еличества] Петра Великого пожалован покойному отцу их), грамоты." ${ }^{21}$ Таким образом условный некогда подарок превращается в реальность.

Необходимо подчеркнуть, что как Зотов, так и Лакоста занимали видное положение при Петре. Зотов был генерал-президентом Ближней канцелярии Сената и, вместе с А. Д. Меншиковым, Ф. М. Апраксиным, Б. П. Шереметевым, Г. И. Головкиным, П. П. Шафировым и К. Х. Патрекеевым, принадлежал к избранному кружку “принципалов" или “верховных господ” при Сенате; ${ }^{22}$ он был также тайным советником. ${ }^{23}$ Лакоста, как мы видели, именовался “генеральным церемониймейстером," сопровождал Петра при поездке в Париж в 1717 г., причем отнесен был к первому разряду лиц придворной свиты; оклад Лакосты в двадцать раз превышал оклады придворных шутов. ${ }^{24}$

principales Révolutions de cet Empire, E les Guerres des Russes contre les Turcs \& les Tartares [...] (t. I-II. Lyon, 1772), II, 71-72; также: Б.А. Успенский, А.Б. Шишкин, “Тредиаковский и янсенисты.” В изд.: Б.А. Успенский, Вокруг Тредиаковского: Труды по истории русского языка и русской культуры (М., 2008), 319-456, здесь 373.

${ }^{18}$ См.: Хоруженко, Дворянские дипломы, 50 (Хоруженко ошибочно полагает, что речь идет о острове Готланд).

${ }^{19}$ В Аннинское время в Преображенском полку служил каптенармус Лакостов, возможно, сын Лакосты. См.: Успенский и Шишкин, “Тредиаковский и янсенисты,” 444.

${ }^{20}$ Хоруженко, Дворянские дипломы, 50-51.

${ }^{21}$ Сенатский архив (т. I-XV. СПб., 1888-1913), III, 267-268. Иск был подан сразу после смерти Лакосты: еще в сентябре 1740 г. он был жив (см.: Хоруженко, Дворянские дипломы, 49).

Жалованная грамота на “графство Сомерс" заканчивалось словами: “Во увъреніе того и на памят[ь] его Господина Церемоніи Мейстера Генералного в предбудущеи Өамиліи дадеся сия наша Ц[а]рского величества м[и]лостивая жалованная Грамота в нашемъ Өлоте на карабле Інгерманландъ... августа 3 дни 1718 г." (РГАДА, ф. 154, оп. 2, д. 146 , л. 3 об.; ср. выше, примеч. 15). Возможно, эти слова служили основанием для претензии наследников Лакосты на имущественные владения; на графский титул они при этом не претендовали.

${ }^{22}$ См.: Корсакова, “Зотов Никита Моисеевич," 479.

${ }^{23}$ Древняя российская вивлиофика, IX, 476 ( $\left.{ }^{\circ} \mathrm{XI}\right)$; Хоруженко, Дворянские дипломы, 127, $177\left(\mathrm{~N}^{\circ} 4\right)$.

${ }_{24}$ См.: Хоруженко, Дворянские дипломы, 48-49. Лакоста, между прочим, был 
Отметим, вместе с тем, что Н. М. Зотов был награжден шутовским орденом Иуды-предателя, который до него носил другой участник Всешутейшего собора, князь Юрий Федорович Шаховской (“архидиакон Гедеон,” † 1713 г.). ${ }^{25}$ Между тем Лакоста на святках 1719 г. получил звание “самоедского короля" (или “самоедского хана”) - звание, которое, как отмечал Вебер, всегда было сопряжено с должностью “шутовского советника" (ein lustiger Rath); ${ }^{26}$ ранее (в 1709-1710 гг.) самоедским повелителем именовался Вименей (Вимени / Вымени, † 1710 г.), шут при дворе Петра I, ${ }^{27}$ а после него (с 1711 г.) - Петр Михайлович Полтев († 1714 г.). ${ }^{28}$ Титул “самоедского короля” (или “хана,” “князя” и т. п.) соотносился с Петровским островом в Петербурге, где жили привезенные из Лапландии “самоеды” (т. е. лопари) вместе со своими оленями и куда Петр приезжал для развлечения. ${ }^{29}$

В обоих случаях - как в случае Зотова, так и в случае Лакосты наблюдается определенная преемственность по отношению к предшествующим шутовским ритуалам.

5. Итак, графский титул Зотова и Лакосты не перешел по наследству к их потомкам. Можно ли объяснить это тем, что они были шутами? Не так легко ответить на этот вопрос. С одной стороны, они были не только шутами, но и сановниками. С другой стороны, в петровских шутовских увеселениях, имевших обычно кощунственный и

прапрадедом декабриста П. И. Пестеля. См.: Н.А. Соколова, "Укоренение рода Пестелей в России.” В изд.: Русский сборник: Исследования по истории России, т. VI (2009), 7-15, здесь 13-14.

${ }^{25}$ И.И. Голиков, Дополнения к Деяниям Петра Великаго (т. I-XVIII. M., 1790-1797), X, 235 (о Зотове); [Just Juel], Записки Юста Юля, датского посланника при Петре Великом (1709-1711). Перевод с дат. Ю. Н. Щербачева (М., 1900), 93, 220 (о Шаховском).

Лакоста позднее (при Анне Иоанновне) становится кавалером шутовского ордена Сан-Бенедетто, которым награждались шуты-иностранцы (или, может быть, шуты-католики), см.: [Manstein], Memoires historiques, II, 72. Ср.: Успенский и Шишкин, “Тредиаковский и янсенисты,” 373, 441.

${ }^{26}$ [Weber], Das veränderte Rußland, I, 339 (§ 432); Голиков, Деяния Петра Великаго, VII, 3637; [Catiforo], Житие Петра Великаго императора, 408-409; [Manstein], Memoires historiques, II, 71. Так же (“ein lustiger Rath”) называет Вебер и предыдущего “самоедского короля” П. М. Полтева (см. ниже, примеч. 28); в то же время он таким же образом именует Н. М. Зотова, рассказывая о его потешной (и, вместе с тем, реальной) свадьбе в январе 1715 г. ([Weber], Das veränderte Rußland, I, 20, 62, §§ 107, 245).

${ }^{27}$ ПuБ, V, 148 ( $\left.\mathrm{N}^{\circ} 1638\right)$ и примеч. на с. 562; там же, VII, примеч. на с. 489-490; там же, VIII, примеч. на с. 578; там же, IX, 329-330 ( $\mathrm{N}^{\circ}$ 3356); Записки Юста Юля, 118-119, 142-143. Вименей именовался также “самоедским князем.”

${ }^{28}$ См.: Хоруженко, Дворянские дипломы, 47-49. Полтев мог именоваться “самоедским вице-королем” (см. там же), но Вебер называет его “королем” (Samojedischer König), см.: [Weber], Das veränderte Rußland, I, 20 (§ 107); относительно даты его смерти см. там же, I,29 (§ 151).

${ }^{29}$ [Weber], Das veränderte Rußland, I, 18 (§ 10o); Описание Санктпетербурга и Кроншлота в 1710-м и 1711-м годах. Перевод с нем. с примеч. [А. Ф. Бычкова] (СПб., 186о), 25-26. Ср.: Exacte Relation von der von Sr. Czaarschen Majestät Petro Alexiowitz, an dem grossen Newa Strohm und der Ost-See neu erbaueten Vestung und Stadt St. Petersburg, wie auch von dem Castel Cron Schloss und derselben umliegenden Gegend... Nebst einigen besondern Anmerkungen auffgezeichnet von H. G. Leipzig, 1713. 
непристойный характер, принимало участие едва ли не все его окружение. ${ }^{30}$ Участие в этих увеселениях было обязательным, и разница между шутами и не-шутами представляется не всегда очевидной (иначе обстояло дело позднее, например, в аннинскую эпоху). ${ }^{31}$ В этих условиях новые наименования, такие как титул графа или барона, могли восприниматься как потешные, шутовские. Вообще иностранные титулы и звания, неожиданно появившиеся и распространившиеся в петровской России, сами по себе могли нести в себе элемент буффонады.

Амбивалентный характер титула “граф” мог ощущаться и много позднее. Показательно в этом смысле наименование пародийного литературного персонажа “графом Пронским" у Шаховского в комедии Новый Стерн (1805 г.), ср. затем упоминание “графа Пронского” у Пушкина в Барышне-Крестьянке. ${ }^{32}$ Фамилия Пронских прочно ассоциировалась с княжеским родом, и Шаховской, как и Пушкин, не мог об этом не знать: известны были князья Пронские, тогда как графов Пронских не было. Замена княжеского титула на графский при сохранении родовитой фамилии делало персонаж условным. В записках Д. Н. Свербеева говорится о Д. П. Татищеве, после России при Венском дворе в 1826-1841 гг.: "Несколько раз предлагаемо ему было графское достоинство, он не согласился принять титул, ссылаясь на то, что Татищевы происходят от смоленских удельных князей, хотя и не пользуются вместе со многими захудалыми Рюриковичами княжеством. Чтобы этот отказ увековечить, для своего герба под княжеской мантией принял он в девиз надпись: Не по Грамоте." 33 Условному графскому титулу, выдаваемому “по грамоте,” противопоставляется таким образом княжеский титул, который определяется происхождением, a не дипломом.

\footnotetext{
${ }^{30}$ См.: Семевский, Слово и дело!, 298-330; В.М. Живов, “Культурные реформы в системе преобразований Петра I.” В изд.: В.М. Живов, Разыскания в области истории и предыстории русской культуры (М., 2002), 381-435, здесь, 402-423; Успенский и Шишкин, “Тредиаковский и янсенисты," 442.

31 Отмечая, что среди членов Всешутейшего собора выделяются группы профессиональных шутов и видных профессиональных сановников, В. М. Живов считает нужным подчеркнуть, что это деление не является вполне однозначным, ссылаясь на пример Н. М. Зотова (Живов, “Культурные реформы в системе преобразований Петра I," 405-406).

${ }^{32}$ А. А. Шаховской. Комедии; стихотворения. Вступ. статья, подг. текста и примечания А. А. Гозенпуда. Л., 1961), 735-752; [А. С.] Пушкин, Полное собрание сочинений, т. I-XVI ([М.Л.], 1937-1949), IX: 122. См. подробнее: А. Л. Осповат, "Из пушкинского ономастикона: Граф Пронский.” В изд.: LAUREA LORAE: Сборник памяти Ларисы Георгиевны Степановой. [Отв. редакторы Ст. Гардзонио, Н. Н. Казанский, Г. А. Левинтон] (СПб., 2011), 481-486.

33 Записки Дмитрия Николаевича Свербеева (1799-1826 (т. I-II. М., 1899), II, 138; Осповат, "Из пушкинского ономастикона," 485.
} 